\title{
Analisis Algoritma RSA Dan LSB pada One Time Password untuk Financial Technology
}

\author{
Galuh Sitoresmi ${ }^{1}$, Wijanarto ${ }^{2}$ \\ Jurusan Teknik Informatika, Fakultas Ilmu Komputer UDINUS, Semarang \\ Universitas Dian Nuswantoro, Jl. Imam Bonjol 207, telp: (+6224) 3517261

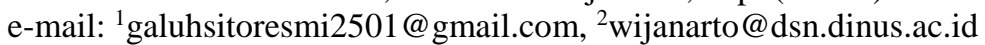

\begin{abstract}
Abstrak
Financial Technology (fintech) merupakan inovasi dibidang pelayanan keuangan yang memanfaatkan teknologi untuk meningkatkan pelayanan dan mempermudah transaksi. Karena berkaitan dengan keuangan, maka keamanan dalam fintech harus kuat dan terjamin. Penyedia layanan fintech seperti GoPay, Paypro, dan T-cash menggunakan One Time Password (OTP) dengan format 4 dan 6 digit bilangan acak numerik yang dikirimkan melalui SMS sebagai solusi autentikasi. Namun kode tersebut mudah terbaca sehingga rawan disalahgunakan oleh orang tidak bertanggung jawab dan dapat merugikan pengguna. Kriptografi merupakan teknik menyandikan informasi ke dalam karakter tertentu dan disusun acak sehingga sulit dimengerti. RSA merupakan algoritma kriptografi yang andal karena menggunakan kunci berbeda untuk menyandikan informasi. Metode LSB merupakan teknik steganografi sederhana untuk menyembunyikan informasi ke dalam citra sehingga mempersulit informasi dapat dibaca dan disalahgunakan. Dengan menerapkan algoritma RSA dan teknik LSB maka dapat meningkatkan keamanan kode OTP, karena kode OTP yang tersembunyi di dalam citra tidak dapat diketahui oleh mata manusia. Hasil dari penelitian ini, kedua algoritma tersebut melakukan keseluruhan proses sangat cepat, durasi rata-rata untuk memproses kode OTP format 4 digit yaitu 0,6738 detik, sedangkan format 6 digit sebesar 0,7005 detik. Hasil kualitas citra stego dengan pengujian MSE dan PSNR memiliki nilai rata-rata yang tinggi yaitu MSE sebesar 0,000531 dan PSNR sebesar 83,110348 dB.
\end{abstract}

Kata kunci: Algoritma, Kriptografi, Steganografi, Financial Technology.

\begin{abstract}
Financial Technology (fintech) is an innovation in the field of financial services that utilizes technology to improve services and facilitate transactions. Because it is related to finance, security in fintech must be strong and guaranteed. Fintech service providers such as GoPay, Paypro, and T-cash use One Time Password (OTP) with a 4 and 6 digit numeric random number format sent via SMS as an authentication solution. However, the code is easy to read so that it is prone to being misused by irresponsible people and can harm users. Cryptography is the technique of encoding information into certain characters and arranged randomly so that it is difficult to understand. RSA is a reliable cryptographic algorithm because it uses different keys to encode information. The LSB method is a simple steganography technique to hide information into an image, making it difficult for information to be read and misused. By applying the RSA algorithm and LSB technique, it can improve the security of the OTP code, because the OTP code hidden in the image cannot be known by the human eye. The results of this study, the two algorithms do the whole process very quickly, the average duration to process the 4-digit format OTP code is 0.6738 seconds, while the 6-digit format is 0.7005 seconds. The results of stego image quality with MSE and PSNR testing have a high average value, namely MSE of 0.000531 and PSNR of $83.110348 d B$.
\end{abstract}

Keywords: Algorithm, Cryptography, Steganography, Financial Technology.

\section{Pendahuluan}

Perusahaan financial technology (fintech) merupakan perusahaan yang menerapkan inovasi baru dibidang pelayanan keuangan dengan memanfaatkan teknologi untuk meningkatkan pelayanan dan mempermudah pengguna dalam bertransaksi, manajemen aset, asuransi, dan menggunakan layanan keuangan [1]. Contoh perusahaan yang menerapkan fintech adalah Gojek dengan GoPay, Telkomsel dengan T-cash, Indosat dengan Paypro, dan sebagainya. Dalam sepuluh tahun, tercatat pertumbuhan pengguna 
fintech di Indonesia naik tajam menjadi $78 \%$ dari sebelumnya hanya $7 \%$ pada tahun 2007 , sebanyak $43 \%$ dari total jumlah 135-140 perusahaan fintech yang tercatat merupakan perusahaan di bidang pembayaran [2].

Karena berkaitan dengan keuangan, maka keamanan sistem pada fintech harus kuat dan terjamin. Penyedia layanan fintech menerapkan two factor authentication menggunakan One Time Password (OTP) sebagai solusi metode autentikasi. OTP merupakan password yang hanya berlaku satu kali pemakaian untuk masuk ke dalam akun pengguna atau untuk persetujuan transaksi online [3].

Urutan angka yang muncul pada OTP dibangkitkan berdasarkan waktu dengan perhitungan rumus tertentu yang dikirimkan oleh server penyedia layanan melalui Short Message Service (SMS) ke nomor handphone pengguna yang didaftarkan pada layanan fintech [3]. Dalam SMS tersebut, ditampilkan kode OTP sebanyak 4 atau 6 digit yang mudah dibaca. Walaupun kode OTP hanya berlaku untuk satu kali pemakaian, namun kode OTP ini merupakan hal yang bersifat rahasia yang hanya boleh diketahui oleh pengguna dan penyedia layanan. Oleh karena itu, kode verifikasi ini tidak boleh diketahui oleh orang lain agar tidak disalahgunakan. Contoh penyalahgunaan kode OTP, seperti pada kasus penipuan akun fintech, yaitu penipu meminta kode verifikasi kepada pemilik akun dengan alasan kesalahan memasukkan nomor handphone karena nomor hampir mirip. Setelah kode diberikan, saldo uang dalam akun pengguna lenyap [4] [5].

Kasus tersebut sangat merugikan pengguna. Oleh karena itu, diperlukan analisis terhadap kode OTP dengan mengimplementasikan teknik kriptografi. Kriptografi adalah teknik menyandikan informasi ke dalam bentuk karakter tertentu dan disusun secara acak sehingga tidak mudah dimengerti. RSA (Rivest Shamir Adleman) merupakan algoritma kriptografi yang andal karena menggunakan kunci yang berbeda pada proses enkripsi dan dekripsi. Algoritma RSA memiliki tingkat keamanan yang tinggi dibanding metode lain pada teknik kunci asimetris karena RSA menggunakan pemfaktoran bilangan prima untuk membangkitkan kunci [6].

Karena teknik kriptografi hanya menyamarkan informasi namun tidak disembunyikan, jadi masih dapat dibaca pihak lain sehingga dapat menimbulkan kecurigaan. Oleh karena itu, maka digunakan teknik steganografi untuk memaksimalkan keamanan[13, 14]. Metode Least Significant Bit (LSB) adalah teknik steganografi yang sederhana dan efektif untuk menyembunyikan informasi ke dalam media lain, sehingga orang awam tidak tahu jika terdapat informasi rahasia yang terdapat di dalam media tersebut [7,15]. LSB bekerja menyisipkan informasi dengan mengganti bit terakhir dari citra cover dengan bit informasi. Teknik LSB memiliki keunggulan yaitu citra hanya mengalami sedikit penurunan kualitas setelah pesan disisipkan ke dalam citra cover, jadi untuk penyisipan informasi pada citra lebih baik menggunakan metode LSB [8].

LSB bekerja dengan baik pada citra lossless dan kurang bagus jika diaplikasikan pada citra lossy karena kompresi citra lossy dapat menghilangkan informasi yang terdapat dalam citra [9,12]. Kompresi lossless digunakan pada citra yang memiliki informasi penting yang tidak boleh hilang atau rusak. BITMAP (*.bmp) merupakan salah satu format citra yang termasuk ke dalam kompresi lossless. Format citra bitmap memiliki hasil terbaik dengan nilai MSE kecil dan PSNR yang tinggi serta waktu rata-rata pemrosesan yang tidak terlalu lambat $[10,11]$.

Penelitian ini bertujuan untuk melakukan analisis terhadap penerapan algoritma kriptografi RSA dan teknik steganografi LSB untuk kode One Time Password pada akun pengguna layanan financial technology yang melakukan transaksi.

\section{Metode Penelitian}

Dalam penelitian ini, disajikan gambaran umum yang berupa langkah-langkah dalam menyelesaikan masalah. Hal ini terkait dengan analisis yang ingin dihasilkan oleh metode seperti gambar 1 di bawah ini. Proses enkripsi dan penyisipan informasi rahasia yang diusulkan pada gambar 1.a adalah:

1. Menentukan jumlah digit bilangan acak 4 atau 6 digit yang dihasilkan menggunakan fungsi rand() dari Matlab sebagai kode OTP.

2. Didapat bilangan acak dengan format 4 atau 6 digit sebagai kode OTP dan mempersiapkan citra cover yang akan digunakan untuk menyisipkan informasi rahasia ke dalam citra.

3. Mengenkripsi kode OTP menggunakan algoritma kriptografi RSA sehingga dihasilkan kode OTP yang telah terenkripsi.

4. Mengubah kode OTP yang telah terenkripsi dan intensitas tiap piksel citra cover ke dalam biner.

5. Melakukan proses penyisipan kode OTP terenkripsi ke dalam citra cover menggunakan teknik steganografi LSB sehingga dihasilkan citra hasil stego.

6. Kemudian citra hasil stego disimpan. 
7. Melakukan evaluasi dengan menggunakan nilai MSE dan PSNR pada citra hasil stego terhadap citra asli.

Proses pengambilan kembali dan dekripsi informasi rahasia yang diusulkan dari gambar 1.b adalah:

1. Mengambil citra hasil stego yang berisi informasi rahasia terenkripsi.

2. Mengubah intensitas tiap piksel citra ke dalam biner.

3. Melakukan pengambilan informasi rahasia yang terdapat dalam citra hasil stego menggunakan teknik steganografi LSB.

4. Dihasilkan dua macam data yaitu data biner informasi rahasia dan data biner intensitas piksel citra. Ubah data biner informasi rahasia ke dalam karakter informasi rahasia terenkripsi dan ubah data biner intensitas piksel ke dalam intensitas citra.

5. Dihasilkan informasi rahasia terenkripsi dan citra hasil decoding.

6. Melakukan dekripsi terhadap informasi rahasia menggunakan algoritma kriptografi RSA.

7. Dihasilkan informasi rahasia kode OTP dengan format 4 atau 6 digit.

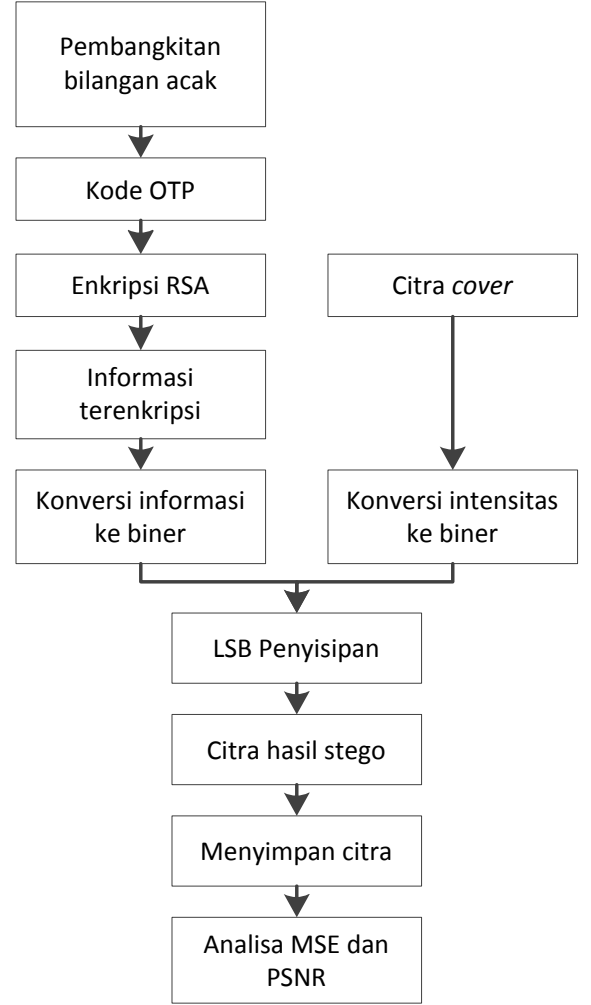

(a)

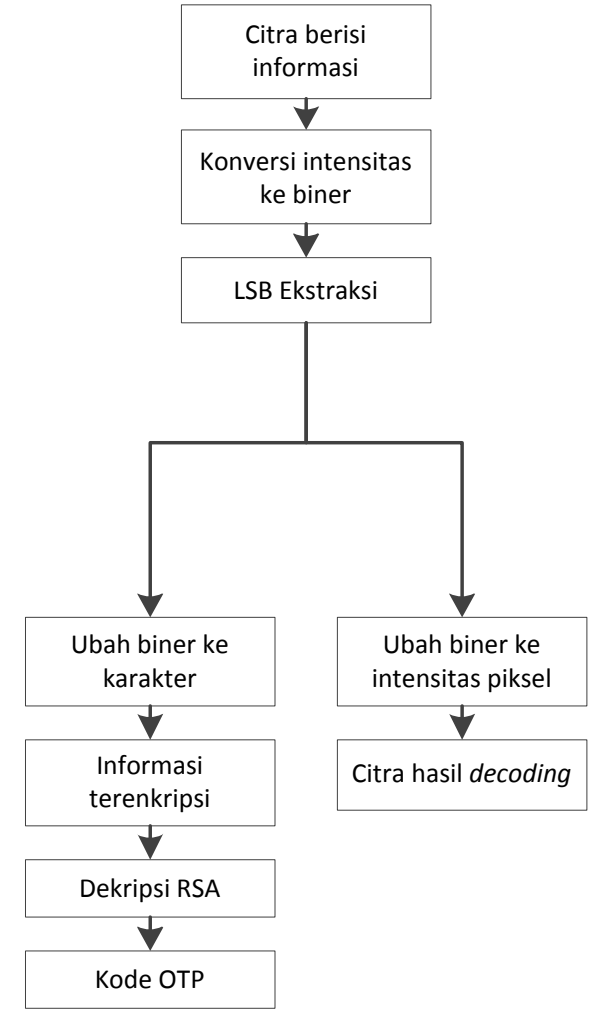

(b)

Gambar 1. Metode yang diusulkan (a) Enkripsi, (b) Dekripsi.

\section{Hasil dan Pembahasan}

Berikut adalah paparan hasil yang dapat disajikan dalam penelitian ini sesuai dengan metode atau langkah yang diusulkan pada bagian sebelumnya.

\subsection{Proses Pembangkitan Kunci RSA}

Proses pada algoritma kriptografi RSA diawali dengan pembangkitan pasangan kunci. Langkah untuk membangkitkan pasangan kunci RSA adalah dengan persamaan dalam $[6,7,11]$ :

1. Memilih sembarang dua bilangan bulat positif prima yang disimpan dalam variable $p$ dan $q$. Dipilih nilai $p=11$ dan $q=31$.

2. Menghitung nilai $n$ menggunakan persamaan: $n=p * q=11 * 31=341$

3. Menghitung $\phi(n)$ dengan menggunakan persamaan: $\phi(n)=(p-1) *(q-1)=(11-1) *(31-1)=300$ 
4. Memilih kunci publik $e$ yang relatif prima terhadap nilai $\phi(n)$. Nilai $e$ yang dipilih yaitu $e=$ 17, karena 17 relatif prima dengan 300.

5. Membangkitkan kunci privat $d$ menggunakan persamaan: $d=\frac{1+k \phi(n)}{e}=\frac{1+(3 \times 300)}{17}=53$

Dengan mencoba nilai $k=1,2,3, \ldots$, didapat nilai $d$ yang bulat yaitu $d=53$. Sehingga dari perhitungan pembangkitan kunci didapatkan pasangan kunci yaitu:

Kunci publik: ( $e=17, n=341)$ untuk proses enkripsi, dan

Kunci privat: $(d=53, n=341)$ untuk proses dekripsi

\subsection{Proses Enkripsi RSA dan Penyisipan LSB}

\subsubsection{Proses Enkripsi RSA}

Plainteks yang digunakan untuk contoh perhitungan enkripsi menggunakan kode OTP dengan format 6 digit yang diperoleh dari pembangkitan bilangan secara random menggunakan fungsi rand() dari Matlab yaitu: $m=648795$

Kemudian plainteks $\mathrm{m}$ dipecah menjadi beberapa blok $m_{1}, m_{2}, \ldots, m_{n}$.

$$
\begin{array}{lll}
m_{1}=6 & m_{3}=8 & m_{5}=9 \\
m_{2}=4 & m_{4}=7 & m_{6}=5
\end{array}
$$

Selanjutnya setiap blok plainteks $m$, di enkripsi menggunakan kunci publik yaitu $e=17$ dan $n=341$. Proses perhitungan enkripsi menggunakan persamaan 1 sebagai berikut:

$$
c_{i}=m_{i}^{e} \bmod n
$$

Proses perhitungan untuk setiap blok plainteks yaitu:

$$
\begin{aligned}
c_{1} & =6^{17} \bmod 341 \\
& =6^{(16+1)} \bmod 341 \\
& =\left(6^{16} \times 6^{1}\right) \bmod 341 \\
& =\left(\left(6^{16} \bmod 341\right) \times\left(6^{1} \bmod 341\right)\right) \bmod 341 \\
& =(335 \times 6) \bmod 341=\mathbf{3 0 5} \\
\cdots . . & \\
c_{6} & =5^{17} \bmod 341 \\
& =5^{(16+1)} \bmod 341 \\
& =\left(5^{16} \times 5^{1}\right) \bmod 341 \\
& =\left(\left(5^{16} \bmod 341\right) \times\left(5^{1} \bmod 341\right) \bmod 341\right. \\
& =(5 \times 5) \bmod 341=\mathbf{2 5}
\end{aligned}
$$

Dari proses enkripsi plainteks menggunakan algoritma kriptografi RSA di atas, maka diperoleh cipherteks $c=3051622048125$

\subsubsection{Proses Penyisipan LSB}

Pada bagian ini akan mengimplementasikan teknik LSB dengan langkah-langkah sebagai berikut $[8,9]:$

1. Mempersiapkan informasi rahasia

Misalkan cipherteks kode OTP yang akan disisipkan ke dalam citra cover diperoleh dari enkripsi plainteks pada proses sebelumnya yaitu $c=30516220481$ 25. Pada proses LSB ini, cipherteks yang masih dalam bentuk integer, masing-masing diubah menjadi biner 16 bit: 000000010011000100000000000100000000000000000010 000000001100110000000000010100010000000000011001

2. Mempersiapkan citra cover sebagai media penyisipan informasi rahasia.

Proses penyisipan menggunakan teknik steganografi LSB, tiap bit informasi rahasia akan menggantikan bit terakhir tiap piksel citra cover [16], di mana jumlah piksel yang digunakan untuk penyisipan adalah sejumlah panjang informasi rahasia yang akan disisipkan. Berikut citra cover yang akan digunakan: 


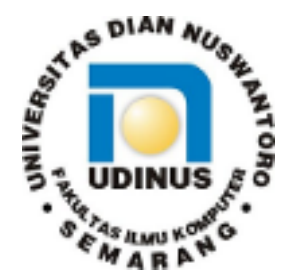

Gambar 2. Citra cover.

3. Melakukan proses steganografi menggunakan teknik LSB.

Berikut contoh proses penyisipan serta perubahan nilai intensitas piksel sebelum dan sesudah disisipi oleh bit cipherteks yang disajikan dalam tabel 1 di bawah ini:

Tabel 1. Proses penyisipan.

\begin{tabular}{ccc}
\hline \multicolumn{2}{c}{ Nilai piksel sebelum disisipi } & \multirow{2}{*}{ Bit cipherteks } \\
\hline Desimal & Biner & \\
\hline 255 & 11111111 & 0 \\
\hline 255 & 11111111 & 0 \\
\hline 255 & 11111111 & 1 \\
\hline 255 & 11111111 & \\
\hline
\end{tabular}

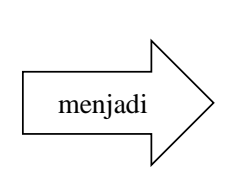

\begin{tabular}{cc}
\hline \multicolumn{2}{c}{ Nilai piksel setelah disisipi } \\
\hline Biner & Desimal \\
\hline 11111110 & 254 \\
\hline 11111110 & 254 \\
\hline 11111111 & 255 \\
\hline 11111110 & 254 \\
\hline
\end{tabular}

4. Menyimpan citra hasil penyisipan

Citra hasil penyisipan kemudian disimpan. Perbandingan citra cover dan citra stego dapat juga dilihat dari histogramnya, yang dapat dilihat pada tabel 2 berikut:

Tabel 2. Perbandingan citra cover dan citra stego.

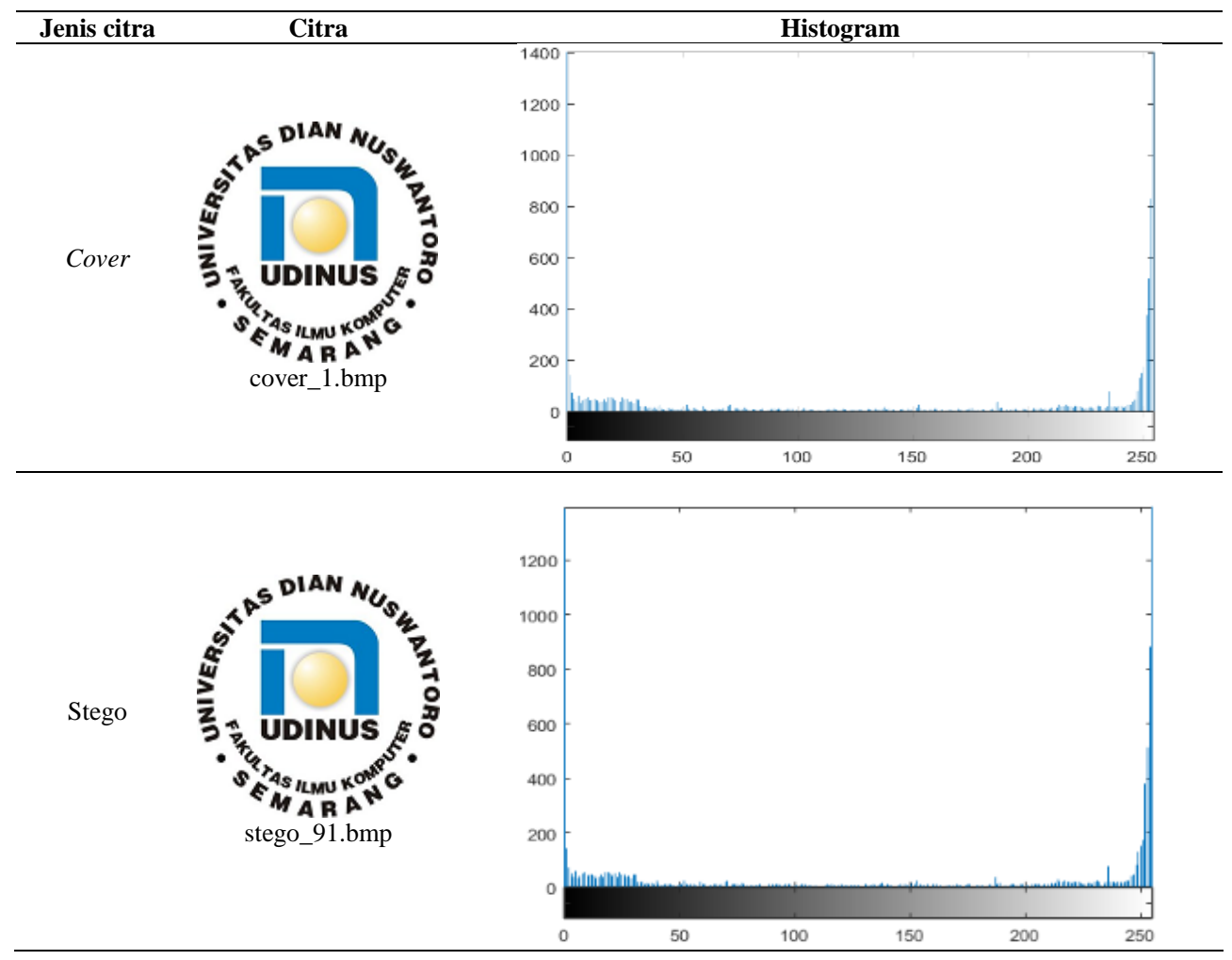

Berikut hasil perbandingan histogram citra cover dan citra stego pada layer Red pada Tabel 3:

Tabel 3. Perbandingan histogram citra pada layer red.

\begin{tabular}{ccc}
\hline Range & Citra Cover & Citra Stego \\
\hline Gradien Warna & $0-255$ & $0-255$
\end{tabular}




\begin{tabular}{ccc}
\hline Mean & 194,17 & 194,17 \\
\hline Median & 255 & 255 \\
\hline Standar Deviasi & $\mathbf{9 9 , 7 0}$ & $\mathbf{9 9 , 7 0}$ \\
\hline Pixels & 16384 & 16384 \\
\hline Percent & 100 & 100 \\
\hline
\end{tabular}

\subsection{Proses Ekstraksi LSB dan Dekripsi RSA}

\subsubsection{Proses Ekstraksi LSB}

1. Mempersiapkan citra yang mengandung informasi.

Pada proses ekstraksi dibutuhkan citra yang mengandung informasi rahasia yang akan dikeluarkan.

2. Membaca intensitas piksel yang berisi informasi

Dibutuhkan informasi panjang informasi rahasia yang disisipkan 4 atau 6 digit kode OTP, serta panjang biner informasi rahasia pada setiap blok, di mana pada penelitian ini setiap blok informasi rahasia memiliki panjang biner 16 bit. Hal ini diperlukan untuk mempermudah pada proses ekstraksi.

3. Mengambil bit terakhir nilai piksel

Nilai piksel diubah ke biner, kemudian bit terakhir atau bit paling akhir dari nilai piksel citra diambil dan disusun kembali menjadi bit-bit biner informasi cipherteks kode OTP. Contoh prosesnya dapat dilihat pada Tabel 4 berikut:

Tabel 4. Proses Ekstraksi LSB.

\begin{tabular}{ccc}
\hline \multicolumn{2}{c}{ Nilai piksel citra stego } & $\begin{array}{c}\text { Bit cipherteks } \\
\text { terekstrak }\end{array}$ \\
\hline Desimal & Biner & $\longrightarrow 0$ \\
\hline 254 & 11111110 & $\longrightarrow 0$ \\
\hline 254 & 11111110 & $\longrightarrow 0$ \\
\hline 255 & 11111111 & $\longrightarrow$ \\
\hline 254 & 11111110 & $\longrightarrow 0$ \\
\hline
\end{tabular}

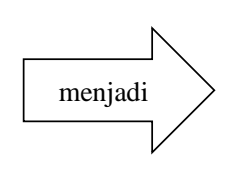

\begin{tabular}{cc}
\hline \multicolumn{2}{c}{ Nilai piksel setelah diekstraksi } \\
\hline Biner & Desimal \\
\hline 11111111 & 255 \\
\hline 11111111 & 255 \\
\hline 11111111 & 255 \\
\hline 11111111 & 255 \\
\hline
\end{tabular}

4. Hasil Ekstraksi

Dari proses ekstraksi, dihasilkan dua data yaitu biner citra hasil ekstraksi dan biner cipherteks. Biner citra hasil ekstraksi kemudian dijadikan desimal sehingga didapat nilai piksel citra. Hasil ekstraksi cipherteks dalam biner yang dihasilkan yaitu:

\section{$\mathrm{C}=000000010011000100000000000100000000000000000010$} 000000001100110000000000010100010000000000011001

Hasil di atas masih berupa satu blok cipherteks, kemudian ubah setiap 16 bit biner menjadi desimal, sehingga diperoleh $\mathrm{C}=3051622048125$

\subsubsection{Proses Dekripsi RSA}

Cipherteks yang digunakan untuk contoh perhitungan dekripsi menggunakan cipherteks yang diperoleh dari proses ekstraksi sebelumnya, yaitu $c=3051622048125$. Kemudian cipherteks $c$ dipecah kembali menjadi beberapa blok $c_{1}, c_{2}, \ldots, c_{n}$, menjadi:

$$
\begin{array}{lll}
c_{1}=305 & c_{3}=2 & c_{5}=81 \\
c_{2}=16 & c_{4}=204 & c_{6}=25
\end{array}
$$

Selanjutnya setiap blok cipherteks $c$, didekripsi menggunakan kunci privatnya yang didapat dari proses pembangkitan kunci sebelumnya yaitu $d=53$ dan $n=341$. Proses perhitungan dekripsi menggunakan persamaan (1), Proses perhitungan untuk setiap blok plainteks yaitu:

$$
\begin{aligned}
m_{1} & =305^{53} \bmod 341 \\
& =305^{(32+16+4+1)} \bmod 341 \\
& =\left(305^{32} \times 305^{16} \times 305^{4} \times 305^{1}\right) \bmod 341 \\
& =\left(\left(305^{32} \bmod 341\right) \times\left(305^{16} \bmod 341\right) \times\left(305^{4} \bmod 341\right) \times\left(305^{1} \bmod 341\right) \bmod 341\right. \\
& =(273 \times 36 \times 191 \times 305) \bmod 341 \\
& =(((273 \times 36) \bmod 341) \times((191 \times 305) \bmod 341)) \bmod 341 \\
& =(280 \times 285) \bmod 341=6 \\
\ldots \ldots & \\
m_{6} & =25^{53} \bmod 341 \\
& =25^{(32+16+4+1)} \bmod 341 \\
& =\left(25^{32} \times 25^{16} \times 25^{4} \times 25^{1}\right) \bmod 341 \\
& =\left(\left(25^{32} \bmod 341\right) \times\left(25^{16} \bmod 341\right) \times\left(25^{4} \bmod 341\right) \times\left(25^{1} \bmod 341\right)\right) \bmod 341
\end{aligned}
$$




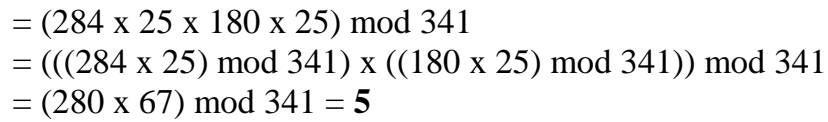

Sehingga diperoleh plainteks kembali dari dekripsi cipherteks, yaitu $m=648795$

\subsection{Hasil Durasi Waktu Pemrosesan}

Berikut diberikan grafik durasi waktu yang diperlukan untuk melakukan keseluruhan proses menggunakan metode yang diusulkan. Dari grafik pada Gambar 3 di atas, dapat dilihat melalui garis yang menunjukkan durasi total proses enkripsi, penyisipan, ekstraksi, dan dekripsi pada kode OTP dengan format 4 digit yang dilakukan sebanyak 30 kali. Durasi tertinggi pada percobaan ini yaitu 0,8847 detik yang merupakan durasi dari citra "cover_2.bmp" pada percobaan ke-30. Untuk waktu terendah yaitu 0,5308 detik, merupakan durasi dari citra "cover_1.bmp" pada percobaan ke-16. Durasi waktu mengalami kenaikan dan penurunan pada rentang 0,5300 - 08850 detik. Waktu terlama yang dibutuhkan untuk melakukan total proses enkripsi, penyisipan, ekstraksi, dan dekripsi pada kode OTP dengan format 4 digit adalah 0,8847 detik. Sedangkan waktu tercepat adalah 0,5308 detik, serta rata-rata durasi total yang dibutuhkan adalah 0,6738 detik.

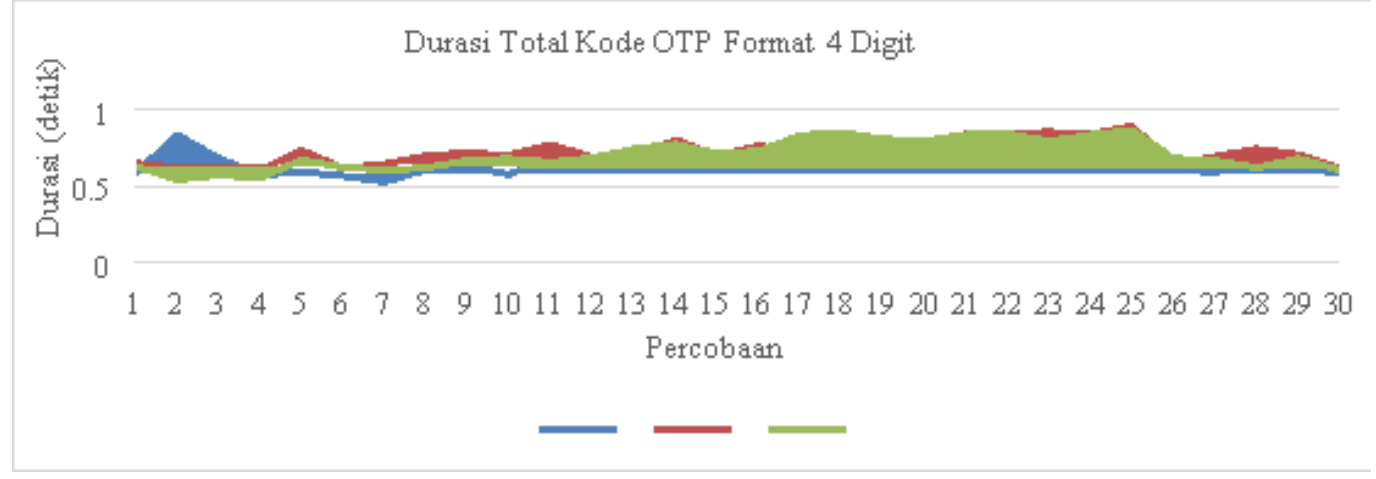

Gambar 3. Grafik durasi total proses kode OTP format 4 digit.

Dari grafik pada Gambar 4 di bawah dapat dilihat melalui garis yang menunjukkan durasi total waktu proses enkripsi, penyisipan, ekstraksi, dan dekripsi pada kode OTP dengan format 6 digit yang dilakukan sebanyak 30 kali. Durasi tertinggi pada percobaan ini yaitu 0,8933 detik yang merupakan durasi dari citra "cover_2.bmp" pada percobaan ke-25. Untuk waktu terendah yaitu 0,5282 detik, merupakan durasi dari citra "cover_1.bmp" pada percobaan ke-7. Berdasarkan grafik pada gambar 4.17, durasi waktu mengalami kenaikan dan penurunan pada rentang 0,5250 - 08950 detik. Waktu terlama yang dibutuhkan untuk melakukan total proses enkripsi, penyisipan, ekstraksi, dan dekripsi pada kode OTP dengan format 6 digit adalah 0,8933 detik. Untuk waktu tercepat adalah 0,5282 detik, serta rata-rata durasi total yang dibutuhkan adalah 0,7005 detik.

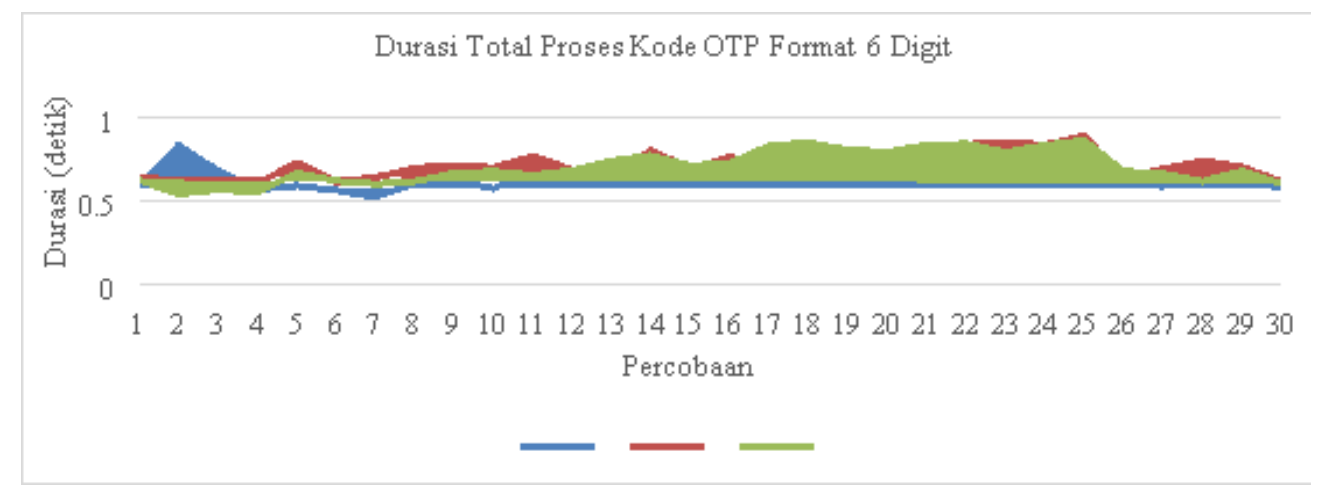

Gambar 4. Grafik durasi total proses kode OTP format 4 digit. 


\subsection{Hasil Evaluasi}

Bagian ini melakukan evaluasi untuk mengetahui kualitas citra hasil penyisipan terhadap citra cover menggunakan nilai MSE dan PSNR. MSE (Mean Square Error) digunakan untuk mengetahui tingkat kesalahan atau error yang terdapat dalam citra hasil terhadap citra cover. Semakin kecil nilai MSE maka semakin bagus kualitas citra hasil. Berikut persamaan 2 perhitungan MSE:

$$
M S E=\frac{1}{M N} \sum_{x=1}^{M} \sum_{y=1}^{N}\left(S_{x y}-C_{x y}\right)^{2}
$$

dengan $x$ dan $y$ adalah koordinat citra, $S_{x y}$ adalah citra stego dan $C_{x y}$ adalah cover citra, yang menghasilkan nilai MSE sebesar $\mathbf{0 , 0 0 1 3 6 3 .}$

Peak Signal Noise Ratio (PSNR) digunakan untuk membandingkan kualitas citra sebelum dan sesudah disisipi cipherteks informasi rahasia kode OTP. Semakin tinggi nilai PSNR sebuah citra hasil maka semakin bagus kualitas dan semakin mirip pula citra itu dengan citra cover. Berikut persamaan 3 untuk menghitung nilai PSNR:

$$
P S N R=10 \log _{10}\left(\frac{C_{\max }^{2}}{M S E}\right)
$$

dalam penelitian ini nilai yang di hasilkan adalah sebesar 76,785468 dan secara keseluruhan distribusi rata-rata nilai MSE dan PSNR disajikan dalam tabel 5 berikut di bawah ini.

\begin{tabular}{|c|c|c|c|}
\hline Ukuran citra & Format kode OTP & Rata-rata MSE & Rata-rata PSNR \\
\hline $128 \times 128$ & \multirow{3}{*}{4 digit } & 0,000946 & 78,379441 \\
\hline $256 \times 256$ & & 0,000276 & 83,728935 \\
\hline $512 \times 512$ & & 0,000689 & 89,749537 \\
\hline $128 \times 128$ & \multirow{3}{*}{6 digit } & 0,001394 & 76,692703 \\
\hline $256 \times 256$ & & 0,000397 & 82,151221 \\
\hline $512 \times 512$ & & 0,000104 & 87,960252 \\
\hline \multicolumn{2}{|c|}{$\sum$ Rata-rata } & 0,000531 & 83,110348 \\
\hline
\end{tabular}

Tabel 5. Nilai MSE dan PSNR Terbaik Keseluruhan.

Pada tabel 5 di atas dapat dilihat rata-rata nilai MSE dan PSNR untuk tiap ukuran citra beserta format kode OTP yang disisipkan dalam citra. Dari tabel 4.34 nilai rata-rata MSE terendah yaitu 0,000104 dari citra berukuran 512 x 512 piksel yang disisipi kode OTP format 6 digit, dan nilai MSE tertinggi yaitu 0,001394 dari citra berukuran 128 x 128 piksel yang disisipi kode OTP format 6 digit. Dari keseluruhan percobaan yang dilakukan maka diperoleh rata-rata nilai MSE sebesar 0,000531. Untuk nilai rata-rata PSNR terendah yaitu 76,692703 dB dari citra berukuran 128 x 128 piksel yang disisipi kode OTP format 6 digit, dan nilai PSNR tertinggi yaitu $89,749537 \mathrm{~dB}$ dari citra berukuran 512 × 512 piksel yang disisipi kode OTP format 4 digit. Dari keseluruhan percobaan yang dilakukan maka diperoleh rata-rata nilai PSNR sebesar 83,110348 dB.

Berdasarkan rata-rata nilai MSE dan PSNR pada masing-masing ukuran citra, citra dengan ukuran 512 x 512 piksel yang disisipi kode OTP dengan format 6 digit memiliki kualitas terbaik pada percobaan ini karena memiliki nilai rata-rata MSE yang rendah dan nilai rata-rata PSNR yang tinggi.

\section{Kesimpulan}

Berdasarkan hasil penelitian yang sudah dilakukan, berikut hasil dari penelitian yang telah dilakukan oleh penulis:

\subsection{Hasil Durasi Waktu Pemrosesan}

Hasil rata-rata durasi proses enkripsi dengan algoritma RSA untuk 30 kali percobaan pada kode OTP format 4 digit sebesar 0,001953 detik, sedangkan dengan format 6 digit sebesar 0,001870 detik. Hasil rata-rata durasi proses penyisipan dengan LSB pada kode OTP format 4 digit sebesar 0,335004 detik, sedangkan dengan format 6 digit sebesar 0,35076 detik. Hasil rata-rata durasi pada proses ekstraksi dengan LSB pada kode OTP format 4 digit sebesar 0,3346 detik, sedangkan dengan format 6 digit sebesar 0,3467 detik. Hasil rata-rata durasi pada proses dekripsi dengan algoritma RSA pada kode OTP format 4 digit sebesar 0,0014 detik, sedangkan dengan format 6 digit sebesar 0,0016 detik. Hasil rata-rata untuk 
melakukan keseluruhan proses enkripsi, penyisipan, ekstraksi dan dekripsi pada kode OTP format 4 digit sebesar 0,6738 detik, sedangkan pada kode OTP format 6 digit sebesar 0,7005 detik.

\subsection{Hasil evaluasi MSE dan PSNR}

Algoritma kriptografi RSA dan teknik steganografi LSB, sebelumnya digunakan oleh Richard Apau dan Clement Adomako [11]. Hasilnya nilai rata-rata MSE adalah 0,0336 sedangkan nilai rata-rata PSNR adalah 63,6032 dB. Berdasarkan nilai MSE dan PSNR tersebut, penelitian yang dilakukan penulis hasilnya lebih tinggi yaitu MSE sebesar 0,000531 dan nilai PSNR sebesar 83,110348 dB dibanding hasil pada penelitian [11], sehingga penelitian yang dilakukan penulis lebih baik. Serta diperoleh citra dengan ukuran 512 x 512 piksel yang disisipi kode OTP format 6 digit memiliki kualitas terbaik pada percobaan ini, dengan nilai rata-rata MSE 0,000104 serta nilai rata-rata PSNR 87,960252 dB. Panjang dan variasi angka pada kode OTP yang disisipkan serta ukuran citra sangat mempengaruhi nilai MSE dan PSNR.

Dari hasil durasi waktu untuk memproses kode OTP dengan format 4 dan 6 digit menggunakan metode yang diusulkan dapat dikatakan sangat cepat. Karena pada praktiknya dibutuhkan waktu yang cepat untuk mengeksekusi proses ini, sehingga dengan durasi rata-rata yang diperoleh tidak sampai 1 detik menandakan algoritma kriptografi RSA dan teknik steganografi LSB yang diajukan untuk kode OTP berhasil. Dari evaluasi nilai MSE dan PSNR diperoleh nilai yang tinggi, menandakan kualitas citra stego sangat bagus dan hampir mirip citra aslinya. Selain itu, kode OTP yang terdapat dalam citra stego dapat diambil kembali dan didekripsi menjadi kode OTP semula. Jadi, citra stego yang mengandung kode OTP yang dihasilkan dari penelitian ini dapat menjadi solusi untuk menghindarkan pengguna layanan fintech dari kejahatan penyalahgunaan kode OTP oleh orang tidak bertanggung jawab. Sehingga penerapan algoritma kriptografi RSA dan teknik steganografi LSB untuk kode OTP yang diajukan penulis berhasil dilakukan.

\section{Saran}

Dari hasil penelitian yang telah dilakukan oleh penulis, maka diharapkan penelitian selanjutnya dapat mengembangkan beberapa hal berikut:

1. Dilakukan pemilihan piksel yang digunakan untuk penyisipan pada citra cover, sehingga lokasi penyisipan lebih acak dan tidak mudah diketahui serta bertujuan untuk mengetahui pengaruh pada hasil MSE dan PSNR

2. Kemungkinan pemilihan parameter nilai $\mathrm{p}$ dan $\mathrm{q}$ yang lebih besar pada pembangkitan kunci algoritma RSA, sehingga kunci untuk enkripsi dan dekripsi yang dihasilkan memiliki nilai yang lebih besar.

\section{Daftar Pustaka}

[1] International Monetary Fund, "Fintech and Financial Services : Initial Considerations," pp. 1-49, 2017.

[2] Cekindo, "Perkembangan Teknologi Finansial (Fintech) di Indonesia," 2017. [Online]. Available: http://www.cekindo.com/id/perkembangan-teknologi-finansial-fintech-di-indonesia.html\%0A. [Accessed: 20-Feb-2018].

[3] Shally and G. S. Aujla, "A review of one time password mobile verification," Int. J. Comput. Sci. Eng. Inf. Technol. Res., vol. 4, no. 3, pp. 113-118, 2014.

[4] D. Anastasia, "Waspada Modus Penipuan Baru! Jika Diminta Kode Verifikasi oleh Olshop, Jangan Langsung Percaya - Halaman all - Tribun Jabar," 2017. [Online]. Available: http://jabar.tribunnews.com/2017/07/07/waspada-modus-penipuan-baru-jika-diminta-kodeverifikasi-oleh-olshop-jangan-langsung-percaya. [Accessed: 20-Feb-2018].

[5] S. PUSPITA, "Cerita Pengguna Go-Jek soal Modus Pencurian Saldo Go-Pay - Kompas," 2017. [Online].Available:http://megapolitan.kompas.com/read/2017/06/18/14175361/cerita.pengguna.gojek.soal.modus.pencurian.saldo.go-pay.\%0A. [Accessed: 20-Feb-2018].

[6] R. Tripathi and S. Agrawal, "Comparative Study of Symmetric and Asymmetric Cryptography Techniquesin 2," Int. J. Adv. Found. Res. Comput., vol. 1, no. 6, pp. 2348-4853, 2014.

[7] S. Mittal, S. Arora, and R. Jain, "Data security using RSA encryption combined with image steganography," India Int. Conf. Inf. Process. IICIP 2016 - Proc., 2017.

[8] T. Sahata Pandapotan and T. Zebua, "Analisa Perbandingan Least Significant Bit dan End Of File Untuk Steganografi Citra Digital Menggunakan Matlab,” Semin. Nas. Inov. dan Teknol., no. 3, pp. 604-608, 2016.

[9] R. Roy and S. Changder, "Quality Evaluation of Image Steganography Techniques : A Heuristics based Approach,” Int. J. Secur. Its Apl., vol. 10, no. 4, pp. 179-196, 2016. 
[10] H. Kaur and A. Kakkar, "Comparison of different image formats using LSB Steganography," 4th IEEE Int. Conf. Signal Process. Comput. Control, pp. 97-101, 2017.

[11] R. Apau and C. Adomako, "Design of Image Steganography based on RSA Algorithm and LSB Insertion for Android Smartphones," Int. J. Comput. Appl., vol. 164, no. 1, pp. 975-8887, 2017.

[12] M. F. Alamsyah, "Implementasi Metode Steganografi Least Significant," no. 5, 2015.

[13] S. K. Kulkarni, "A Survey of Password Attacks, Countermeasures and Comparative Analysis of Secure Authentication Methods," Int. J. Adv. Res. Comput. Sci. Manag. Stud., vol. 3, no. 11, pp. 319$331,2015$.

[14] M. L. Das and N. Samdaria, "On the security of SSL / TLS-enabled applications," Appl. Comput. Informatics, vol. 10, no. 1-2, pp. 68-81, 2014.

[15] K. U. Singh, “A Survey on Image Steganography Techniques,” Int. J. Comput. Appl., vol. 97, no. 18, pp. 975-8887, 2014.

[16] "Logo - Fakultas Ilmu Komputer - Udinus Gallery." [Online]. Available: http://dinus.ac.id/gallery2/displayimage.php?pid=2895. [Accessed: 09-Mar-2018]. 